Journal of Pharmaceutical Science and Clinical Research, 2018, 01, 43-49

DOI: $10.20961 /$ jpscr.v3i1.15108

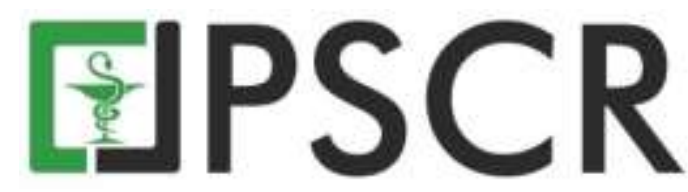

\title{
Efek Antiinflamasi Ekstrak Etanol Krokot (Portulaca oleracea, L.) pada Udema Tikus yang di Induksi Karagenin
}

\author{
Dahlia Andayani $^{1}$, Endang Suprihartini ${ }^{1}$ dan Maulida Astuti ${ }^{1}$ \\ ${ }^{1}$ Fakultas Ilmu Kesehatan Universitas Nahdlatul Wathan Mataram \\ *email korespondensi : dahlia_andayani@ymail.com
}

\begin{abstract}
Abstrak: Krokot (Portulaca oleracea, L.) merupakan tanaman yang dapat digunakan sebagai obat tradisional untuk menyembuhkan penyakit disentri, penyakit kulit, nyeri dan bengkak. Penelitian ini bertujuan Untuk mengetahui efek antiinflamasi krokot pada tikus yang diinduksi karagenin. Rancangan Penelitian menggunakan pre and post test only control group design dengan lima kelompok perlakuan yaitu kelompok I sebagai kontrol negatif, kelompok II kontrol positif (Na diklofenak dosis 50mg), kelompok III ekstrak etanol krokot dosis $100 \mathrm{mg}$, kelompok IV ekstrak etanol krokot dosis $200 \mathrm{mg}$, kelompok V ekstrak etanol krokot dosis $400 \mathrm{mg}$. Masing masing kelompok terdiri dari 3 ekor tikus. Efek antiinfllamasi dievaluasi dengan menghitung total volume udem pada menit ke 0, 60, 120, 180, 240 dan 300. Hasil penelitian menunjukkan kelima kelompok perlakuan memiliki total volume udem yang berbeda bermakna dengan nilai signifikansi lebih kecil dari 0,05. Dari hasil perhitungan persen daya antiinflamasi diperoleh nilai dari yang tertinggi natrium diklofenak, ekstrak dosis $400 \mathrm{mg}$, ekstrak dosis $200 \mathrm{mg}$ dan ekstrak dosis 100 mg yaitu: 32,95\%, 30,20\%, $20 \%$ dan 16, 73\%. Dari hasil penelitian dapat disimpulkan bahwa ekstrak etanol krokot memiliki efek antiinflamasi pada udem tikus tyang diinduksi karagenin.
\end{abstract}

Kata kunci: Antiinflamasi; krokot; karagenin; udem

Abstract. Antiinflamatory effect of ethanol extract of krokot (Portulaca oleracea, L.) on carageenan induced edema in rats. Krokot (Portulaca oleracea, L) is a plant that can be used as a traditional medicine to cure disentri, skin diseases, pain and swelling. This study aims To determine the anti-inflammatory effect of ethanol extract of Krokot on caragenin induced udem in rats. Design of the research is Pre and Post test only control group desingn with five group treatment. Each group consists of 3 rats. Group I as negative control, group II positive control (Diclofenac doses 50mg), group III ethanol extract krokot doses $100 \mathrm{mg}$, group IV ethanol extract krokot of doses of $200 \mathrm{mg}$, group V extract of ethanol krokot dose $400 \mathrm{mg}$. The antiinflammatory effect was evaluated by calculating the total volume of udem at minutes $0,60,120$, 180, 240 and 300.The results showed that the five treatment groups had a significantly different mean udem volume with a significance value less than 0.05 . From the calculation of percentage of anti-inflammatory power obtained value of the highest diclofenac sodium, ethanol extract 400 $\mathrm{mg}$, ethanol extract $200 \mathrm{mg}$ and ethanol extract $100 \mathrm{mg}$ dose extract are: $32.95 \%, 30.20 \%, 20 \%$ and $16,73 \%$. From the results of this study it can be concluded that ethanol extract of krokot has anti-inflammatory effect on caragenin induced udem in rats.

Keywords: antiinflamation; krokot (Portulaca olearecea); caragenin; oedem 


\section{Pendahuluan}

Inflamasi atau radang merupakan penyakit yang banyak diderita oleh masyarakat biasanya ditandai dengan adanya bengkak, nyeri, kemerahan dan panas. Inflamasi terjadi karena ada respon perlindungan normal terhadap cedera jaringan yang disebabkan oleh trauma fisik, bahan kimia berbahaya, atau agen mikrobiologi. Inflamasi merupakan usaha tubuh untuk menginaktifkan atau menghancurkan organisme penginvasi, menghilangkan iritan dan persiapan tahapan untuk perbaikan jaringan (Harvey \& Pamela, 2013). Obat antiinflamasi yang umumnya digunakan terbagi menjadi dua kelompok besar yaitu antiinflamasi golongan steroid dan antiinflamasi golongan nonsteroid. Namun, kedua golongan obat tersebut memiliki efek samping yang cukup serius pada penggunannya. Karena banyaknya efek samping dari obat-obatan antiinflamasi yang umum digunakan saat ini, maka semakin banyak dikembangkan antiinflamasi yang berasal dari tanaman (Lee et al., 2016).

Salah satu tanaman yang memiliki efek antiinflamasi adalah Tanaman krokot (Portulaca oleracea L) yang dilaporkan oleh Agyare et al., 2015 dengan menggunakan pelarut metanol. Untuk mendapatkan hasil ekstraksi yang menyeluruh dan mendapatkan senyawa senyawa yang mempunyai aktivitas farmakologi maka pemilihan pelarut yang digunakan untuk mengekstraksi merupakan faktor yang penting. Pelarut ideal yang sering digunakan adalah alkohol atau campurannya dengan air karena merupakan pelarut pengekstraksi yang baik untuk hampir semua senyawa dengan berat molekul rendahseperti saponin dan flavonoid (Wijesekera, 1991). Jenis pelarut pengekstraksi juga mempengerhui jumlah senyawa aktif yang terkandung dalam ekstrak sesuai dengan konsep like dissolve like, dimana senyawa yang bersifat polar akan larut dalam pelarut polar dan senyawa yang bersifat non polar akan larut dalam pelarut non polar (Arifianti, 2014). Arifianti melaporkan hasil ekstraksi senyawa turunan flavonoid yaitu sinensetin dari orithoshifon mendapatkan hasil ekstraksi paling baik menggunakan pelarut etanol $96 \%$. Pada penelitian ini pelarut yang digunakan adalah etanol untuk mendapatkan kadar flavonoid yang tinggi. Etanol sering digunakan sebagai pelarut dilaboratorium karena bersifat inert sehingga tidak bereaksi dengan komponen lainnya (Susanti, 2012).

Tanaman krokot (Portulaca oleracea L) adalah anggota dari keluarga portulacaceae dengan lebih dari 120 spesies yang berbeda. Penggunaan tanaman ini sebagai sayur, rempah-rempah dan obat-obatan telah dikenal sejak zaman Mesir kuno dan populer di Inggris (Azuka et al., 2014). Senyawa beragam telah diisolasi dari Tanaman Krokot (Portulaca oleracea L), seperti flavonoid, alkaloid, polisakarida, asam lemak, terpenoid, sterol, vitamin, protein dan mineral. Tanaman krokot (Portulaca oleracea L) juga mengandung asam lemak omega 3 yang biasanya terdapat pada lemak ikan (Zhou et al., 2015).

Berbagai efek farmakologis telah dilaporkan yaitu sebagai antidiabetes (Okoh 2015), antibakteri, antiulcerogenic, anti-inflamasi, antioksidan dan penyembuhan luka. Efek antiinflamasi yang pernah dilaporkan menggunakan ayam sebagai hewan uji yang menunjukkan efek yang positif menurunkan udem. Hasil penelitian Agyare et. al, (2015) menunjukan bahwa ekstrak metanol dari daun dan batang Krokot (Portulaca oleracea L) memiliki efek antiinflamasi pada percobaan dengan menggunakan anak ayam sebagai hewan uji. Hasil penelitiannya menunjukan signifikan pada dosis 100 (p <0,05), 200 (p<0,01) dan 400 (p <0,01) mg/ kg yang diinduksikan karagenin dengan perbandingan menggunakan Aspirin sebagai kontrol positif.

Pada penelitian ini hewan uji yang digunakan adalah tikus karena metabolisme dalam tubuh tikus dan manusia relatif lebih mirip dan dan struktur jaringan pada kaki tikus lebih mudah diberi 
perlakuan subkutan senyawa penginduksi. Metanol dan etanol sama sama merupakan pelarut turunan alkohol, kedua pelarut ini memiliki gugus hidroxyl $(\mathrm{OH})$ dan memiliki rantai karbon (atom C) jumlah atom $\mathrm{C}$ pada pelarut etanol lebih besar yaitu dua atom $\mathrm{C}$ sehingga senyawa ini lebih mampu melarutkan senyawa metabolit sekunder yang bersifat non polar pada tanaman krokot. Penelitian lain juga menyebutkan ekstrak aquades Krokot (Portulaca oleracea L) pada konsentrasi 0,05, 0,1 dan 0,2 mg/ml mampu mengaktifkan RAW 264.7 makrofag tikus dengan menghambat produksi LPS penyebab inflamasi (Kim-Young et al, 2015). Kurangnya informasi tentang herba krokot sebagai obat antiinflamasi yang potensial untuk dikembangkan maka perlu dilakukan uji dengan berbagai metode dan pembanding untuk mempertegas kemungkinan mekanisme aksi herba krokot.

\section{Bahan dan Metode}

\subsection{Alat dan bahan}

Rotary evaporator, pletismometer air raksa (Manual) Bahan yang digunakan adalah herba krokot dari Lombok Barat NTB, etanol $70 \%$ brataco, aquades, CMC 0,5\%, Natrium diklofenak OGB Dexa medica, karagenin $1 \%$.

\subsection{Preparasi sampel uji}

Herba krokot sebanyak 2,6 kg disortasi, dibersihkan dan dikeringkan dibawah sinar matahari selama 3 hari kemudian didapatkan simplisia sebanyak 250 gram. Simplisia yang telah kering diekstraksi dengan metode maserasi menggunakan etanol $70 \%$ sebanyak $1500 \mathrm{ml}$ selama 7 hari. kemudian disaring. Ekstrak cair dipisahkan dari pelarutnya dengan rotary evaporator yang dilakukan di Universitas Mataram.

\subsection{Pembuatan suspensi natrium diklofenak dan karagenin}

Natrium diklofenak 50 mg dan karagenin $1 \%$ disuspensikan dengan CMC 0,5\%.

\subsection{Penentuan Dosis}

Dosis ekstrak herba krokot yaitu $100 \mathrm{mg} / \mathrm{kg} \mathrm{BB}, 200 \mathrm{mg} / \mathrm{kg}$ BB dan $400 \mathrm{mg} / \mathrm{kg}$ BB diberikan secara peroral pada tikus (Agyare, 2015). Dosis karagenin yang disuntikan ditelapak kaki tikus adalah $1 \%$ sebanyak $0,01 \mathrm{ml}$.

\subsection{Penyiapan hewan uji}

Hewan uji yang digunakan adalah tikus jantan, galur wistar sehat, umur 3- 4 bulan dengan BB 150 gram. Semua kelompok diadaptasi selama seminggu di lingkungan laboratorium dan diberi makan ad libitum. Sebelum diberi perlakuan tikus dipuasakan kurang lebih 6 jam.

\subsection{Uji Efek Antiinflamasi}


Uji aktivitas antiinflamasi dilakukan dengan metode induksi karagenin $1 \%$ diberikan secara subplantar pada tikus jantan setelah diberikan perlakuan dengan 5 kelompok perlakuan yang terdiri dari 3 tikus pada masing-masing perlakuan. Kelompok I merupakan kontrol negatife diberi aquades, kelompok II kontrol positif diberi Na diklofenak dosis $50 \mathrm{mg} / \mathrm{kg} \mathrm{BB}$, kelompok III, IV dan V diberikan sampel uji dosis $100 \mathrm{mg} / \mathrm{kg} \mathrm{BB}, 200 \mathrm{mg} / \mathrm{kg}$ BB dan $400 \mathrm{mg} / \mathrm{kg} \mathrm{BB}$. Pengamatan dilakukan selama 300 menit dengan pengukuran volume udem menggunakan pletismometer. Analisa data dengan metode one way ANOVA.

\section{Hasil dan Pembahasan}

Hasil preparasi sampel menunjukkan susut pengeringan sampel segar krokot sebesar 9,6\%, pengeringan menggunakan sinar matahari langsung. Sedangkan rendemen ekstrak yang diperoleh sebesar $41,18 \%$.

Uji antiinflamasi menunjukkan beberapa hasil pengukuran. Hasil pengukuran volume udem sebelum diinduksi dengan karagenin dan setelah diberi perlakuan dapat dilihat pada tabel 1 dan gambar 1. Semua kelompok yang diinduksi dengan karagenin menunjukkan peningkatan volume kaki yang disebut sebagai udem (inflamasi). Inflamasi disebabkan karena Karagenin dapat merangsang pelepasan mediator inflamasi seperti prostaglandin, bradikinin dan leukotrin tanpa merusak jaringan tempat penyuntikan (Apriani, 2011). Dari tabel 1. dan gambar 1. Dapat terlihat bahwa volume udem tertinggi terjadi pada menit ke 180 dan mengalami penurunan setelah menit ke 180. Volume udem rata-rata terbesar pada kelompok perlakuan kontrol negatif dengan nilai rata-rata volume udem tertinggi yaitu $0.013 \mathrm{ml}$ dan terendah yaitu $0.011 \mathrm{ml}$. Hal ini dikarenakan aquades sebagai kontrol negatif hanya berfungsi sebagai pembanding yang tidak memiliki efek antiinflamasi sehingga aquades tidak memilik efek untuk menurunkan pembengkakan pada telapak kaki tikus yang diinduksikan karagenin.

Tabel 1. Volume udem rata-rata \pm SD pada telapak kaki kanan tikus. Nilai signifikansi dengan nilai $\mathrm{P}<0,05$. Kelompok 1: Edema dan Pemberian aquadest; Kelompok 2 : Edema dan Pemberian natrium diclofenac dosis $50 \mathrm{mg}$; Kelompok 3: Edema dan Pemberian ekstrak etanol krokot dosis 100 mg; Kelompok 4 : Edema dan Pemberian ekstrak etanol krokot dosis $200 \mathrm{mg}$; Kelompok 5: Edema dan Pemberian ekstrak etanol krokot dosis $400 \mathrm{mg}$

\begin{tabular}{|c|c|c|c|c|c|c|c|}
\hline \multirow{2}{*}{$\begin{array}{l}\text { Kelompok } \\
\text { Perlakuan }\end{array}$} & \multirow{2}{*}{$\begin{array}{c}\text { Vo. } \\
\text { (sebelum } \\
\text { diinduksikan } \\
\text { karagenin) }\end{array}$} & \multicolumn{6}{|c|}{ Volume edema rata-rata pada menit ke $(\mathrm{Vt}(\mathrm{ml}))$} \\
\hline & & $\begin{array}{c}\text { Setelah } \\
\text { induksi } \\
\text { karagenin }\end{array}$ & 60 & 120 & 180 & 240 & 300 \\
\hline \multirow[t]{2}{*}{$\mathbf{I}$} & 0,0046 & 0,0066 & $\mathbf{0 , 0 0 8 0}$ & $\mathbf{0 , 0 1 1 0}$ & $\mathbf{0 , 0 1 3 0 0}$ & $\mathbf{0 , 0 1 2 0}$ & $\mathbf{0 , 0 1 1 0}$ \\
\hline & $\pm 0,02$ & $\pm 0,012$ & $\pm 0,056$ & $\pm 0,012$ & $\pm 0,764$ & $\pm 0,024$ & $\pm 0,056$ \\
\hline \multirow[t]{2}{*}{2} & 0,0046 & 0,0063 & 0,0070 & $\mathbf{0 , 0 0 8 0}$ & 0,0090 & 0,006 & \\
\hline & $\pm 0,056$ & $\pm 0,02$ & $\pm 0,02$ & $\pm 0,056$ & $\pm \mathbf{0 , 0 3 2}$ & $\pm \mathbf{0 , 0 2 3}$ & 0,0050 \\
\hline \multirow[t]{2}{*}{3} & $\mathbf{0 , 0 0 5 0}$ & 0,0060 & $\mathbf{0 , 0 0 8 0}$ & $\mathbf{0 , 0 0 9 3}$ & $\mathbf{0 , 0 1 1 0}$ & & 0,0076 \\
\hline & $\pm 0,764$ & $\pm 0,012$ & $\pm 0,27$ & $\pm 0,012$ & $\pm 0,02$ & & $\mathbf{\pm 0 , 0 2}$ \\
\hline \multirow[t]{2}{*}{4} & 0,0046 & 0,0063 & 0,0076 & 0,0090 & 0,0100 & $\mathbf{0 , 0 0 9 3}$ & 0,0070 \\
\hline & $\pm 0,27$ & $\pm 0,02$ & $\pm 0,012$ & $\pm 0,02$ & $\pm 0,024$ & $\pm 0,024$ & $\pm 0,27$ \\
\hline \multirow[t]{2}{*}{5} & 0,0043 & 0,0056 & 0,0067 & $\mathbf{0 , 0 0 8 3}$ & 0,0090 & $\mathbf{0 , 0 0 7 3}$ & 0,0056 \\
\hline & $\pm 0,012$ & $\pm 0,764$ & $\pm 0,024$ & $\pm 0,056$ & $\pm 0,056$ & $\pm 0,056$ & $\pm 0,764$ \\
\hline
\end{tabular}


Untuk volume udem rata-rata terkecil pada kelompok perlakuan kontrol positif dengan nilai rata-rata volume udem tertinggi yaitu $0,009 \mathrm{ml}$ dan terendah yaitu $0.005 \mathrm{ml}$. Na diklofenak yang disuspensikan dengan Na CMC $1 \%$ digunakan sebagai kontrol positif mampu menurunkan udem pada kaki tikus yang telah diinduksikan karagenin karena termasuk golongan NSAID dengan aktifitas antiinflamasi, analgetik dan antipiretik. Na CMC dipilih sebagai pensuspensi karena mempunyai toksisitas yang rendah dan terdispersi di dalam air dibandingkan dengan pensuspensi lain (Raymond dan Paul, 2003). Fungsi kontrol positif adalah sebagai pembanding apakah zat uji bisa berefek sama dengan obat antiinflamasi yang digunakan sebagai kontrol positif. Pengukuran volume udem dilakukan selama 300 menit dengan selang waktu tertentu. Untuk mengetahui besarnya daya hambat ekstrak etanol krokot terhadap pembentukan udem maka dilakukan perhitungan AUC (area under curve). Hasil perhitungan AUC dapat dilihat pada tabel 3 .

Tabel 2. Penurunan udema setelah diberikan ekstrak herba krokot. Kelompok 1: Edema dan Pemberian aquadest; Kelompok 2 : Edema dan Pemberian natrium diclofenac dosis 50 mg; Kelompok 3: Edema dan Pemberian ekstrak etanol krokot dosis $100 \mathrm{mg}$; Kelompok 4 : Edema dan Pemberian ekstrak etanol krokot dosis 200 mg; Kelompok 5: Edema dan Pemberian ekstrak etanol krokot dosis 400 mg

\begin{tabular}{lccccccc}
\multirow{2}{*}{$\begin{array}{l}\text { Kelompok } \\
\text { Perlakuan }\end{array}$} & Vo. & \multicolumn{7}{c}{ Penurunan Volume Udem (ml) } \\
\cline { 3 - 8 } & & $(\mathrm{T} 1)$ & T1-T2 & T1-T3 & T1-T4 & T1-T5 & T1-T6 \\
\hline Kelompok 1 & 0,0046 & 0,0066 & $-0,0020$ & $-0,0044$ & $-0,0064$ & $-0,0054$ & $-0,0044$ \\
Kelompok 2 & 0,0046 & 0,0063 & $-0,0007$ & $-0,0017$ & $-0,0027$ & 0,0000 & 0,0013 \\
Kelompok 3 & 0,0050 & 0,0060 & $-0,0020$ & $-0,0033$ & $-0,0050$ & $-0,0036$ & $-0,0016$ \\
Kelompok 4 & 0,0046 & 0,0063 & $-0,0013$ & $-0,0027$ & 0,0063 & $-0,0030$ & $-0,0007$ \\
Kelompok 5 & 0,0043 & 0,0056 & $-0,0011$ & $-0,0027$ & $-0,0034$ & $-0,0017$ & 0,0000 \\
\hline
\end{tabular}

Dari tabel 3 dan gambar 1. diketahui bahwa AUC total tertinggi pada kelompok 1 (aquades) dan AUC terendah pada kelompok 2 (Na diklofenak). Sedangkan nilai persentase daya antiinflamasi berbanding terbalik dengan nilai AUC total. Persentase daya antiinflamasi tertinggi pada kelompok 2 ( Na diklofenak) dengan nilai persentase sebesar 32,95\% yang kemudian diikuti dengan sampel uji kelompok 5 (Ekstrak herba krokot dosis $400 \mathrm{mg}$ ), kelompok 4 (Ekstrak herba krokot dosis $200 \mathrm{mg}$ ) dan kelompok 3 (Ekstrak herba krokot dosis $100 \mathrm{mg}$ ) dengan nilai daya antiinflamasi berturut-turut $30.20 \%, 20.00 \%$ dan $16.73 \%$. Sedangkan untuk kelompok 1 (aquades) yaitu $0 \%$ karena tidak memiliki aktivitas daya antiinflamasi. Na diklofenak sebagai obat dengan mekanisme kerja menghambat enzim cyclooxygenase (COX-1 dan COX -2 ) sehingga menghambat pelepasan mediator radang seperti prostaglandin sehingga mampu mengobati inflamasi pada kaki tikus (Joel et al, 2007).

Untuk sampel uji ekstrak herba krokot pada dosis $400 \mathrm{mg}$ memilik aktivitas antiinflamasi yang lebih baik dari dosis $100 \mathrm{mg}$ dan $200 \mathrm{mg}$, hal ini mungkin disebabkan oleh semakin tinggi kadar zat aktif yang terkandung didalamnya maka semakin banyak yang memberikan aktivitas antiinflamasi, yang artinya zat aktif pada dosis tersebut sudah mempunyai kemampuan untuk menurunkan volume udem yang sama dengan suspense natrium diklofenak bila dibandingan 
dengan dosis $100 \mathrm{mg}$ dan $200 \mathrm{mg}$. Hasil ini sama dengan penelitian yang pernah dilakukan oleh Agyare et al, (2015) dengan hewan uji kaki ayam yang mengatakan dosis $400 \mathrm{mg} / \mathrm{kg} \mathrm{BB}$ memiliki efek antiinflamasi yang lebih baik dari dosis 100 dan $200 \mathrm{mg} / \mathrm{kg} \mathrm{BB}$. Kemampuan ekstrak herba krokot dapat berefek antiinflamasi diduga disebabkan oleh metabolit sekunder yang terkandung didalamnya antara lain flavanoid, terpenoid dan steroid (Zhou et al., 2015).

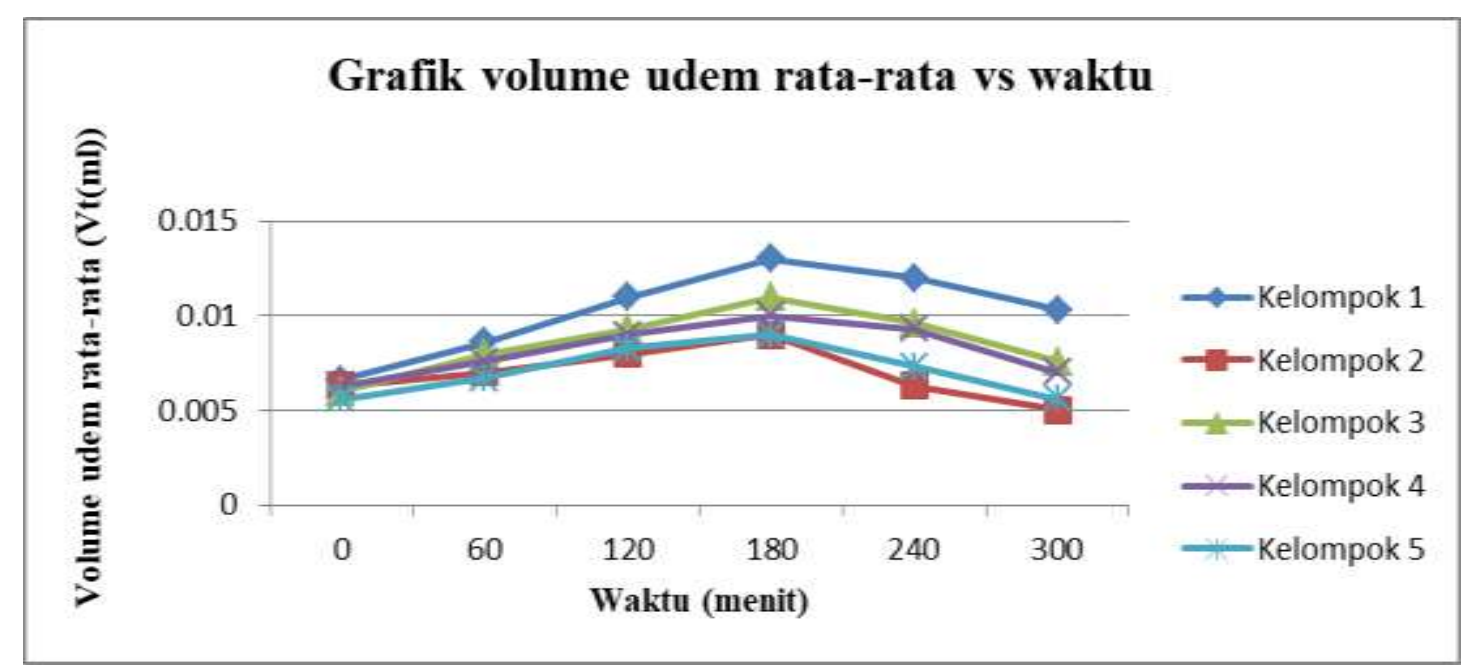

Gambar 1. Grafik volume udem rata-rata vs waktu

Tabel 3. Persentase (\%) daya antiinflamasi dan hasil uji Anova. Nilai signifikansi dengan nilai $\mathrm{P}<0,05$.

\begin{tabular}{|c|c|c|c|}
\hline No & Kelompok perlakuan & AUC Total & $\begin{array}{c}\% \text { Daya } \\
\text { Antiinflamasi }\end{array}$ \\
\hline 1 & Kelompok 1 & $9,8^{\mathrm{a}}$ & $0 \%$ \\
\hline 2 & Kelompok 2 & $6,57^{a, b}$ & $32,95 \%$ \\
\hline 3 & Kelompok 3 & $8,16^{a}$ & $16,73 \%$ \\
\hline 4 & Kelompok 4 & $7,83^{a, b}$ & $20,00 \%$ \\
\hline 5 & Kelompok 5 & $6,84^{a}$ & $30,20 \%$ \\
\hline
\end{tabular}

Data uji statistik One Way Anava nilai AUC menunjukkan hasil yang signifikan yaitu nilai P $<0,05$ menunjukkan bahwa ada pengaruh pemberian ekstrak etanol herba krokot terhadap penurunan volume udem tikus yang diinduksi karagenin (Tabel 2). Dengan uji tukey dapat diketahui Perbedaan yang tidak signifikan (tidak berbeda bermakna) antara nilai AUC Kelompok 5 yang diberikan ekstrak herba krokot dosis $400 \mathrm{mg} / \mathrm{kg}$ BB dengan kelompok 2 yang diberikan Natrium diklofenak dosis $50 \mathrm{mg} / \mathrm{kg}$ BB. Hasil ini menunjukkan bahwa ekstrak etanol krokot dosis $400 \mathrm{mg} / \mathrm{kg}$ BB memeliki efek yang sama secara statistik dengan natrium diklofenak. Jadi semakin tinggi dosis herba krokot dalam etanol $70 \%$ efek antiinflamasi herba krokot semakin besar hal ini sesuai dengan hasil penelitian dari Kim-Young et al, 2015 yaitu ekstrak herba krokot yang diekstak dengan akuades mampu menghambat enzim yang mengasilkan mediator inflamasi. 


\section{Kesimpulan}

Hasil data statistik dengan One Way Anova didapatkan nilai signifikan adalah 0,00 < 0,05 ini berarti ekstrak herba krokot memiliki efek antiinflamasi pada tikus jantan yang diinduksikan karagenin. Besarnya daya antiinflamasi natrium diklofenak adalah 32,95\%, ekstrak etanol krokot dosis $400 \mathrm{mg} 30,20 \%$, ekstrak etanol krokot dosis $200 \mathrm{mg}$ adalah $20 \%$, ekstrak etanol krokot dosis $100 \mathrm{mg}$ adalah 16,73\%, dari hasil tersebut dapat disimpulkan bahwa ektrak etanol krokot memiliki efek antiinflamasi pada udem kaki tikus yang diinduksi karagenin.

\section{Ucapan Terima Kasih}

Terima kasih pada Fakultas Ilmu Kesehatan Universitas Nahdlatul Wathan Mataram atas fasilitas yang sudah dan berikan.

\section{Daftar Pustaka}

Agyare C., Eunice B., John A., Yan D. \& Louis A., 2015, Anti-infective and Anti-inflammatory Properties of Portulaca oleracea L, Journal of Medicinal Plant Research, 2(1) : 001-006.

Apriani D. R., 2011, Uji Efek Antiinflamasi Kombinasi Ekstrak Air Akar Tanaman Akar Kucing (Acalypha Indica Linn) Dan Ekstrak Etanol 70\% Rimpang Jahe Merah (Zingiber Officinale Rose) Terhadap Udem Telapak Kaki Tikus Yang Diinduksi Karagenin. Skripsi : Fakultas Dan Ilmu Pengetahuan Alam Program Studi Farmasi Depok.

Arifianti susanti, Oktarina, R.D., Kusumawati, I, 2014, pengaruh jenis pelarut pengektraksi terhadap kadar sinensetin dalam ektrak daun orthosiphon stamineus benth. E-Journal Planta Husada ;2( 1).

Azuka O., Ayalokunrin M. \& Orachu L., 2014, Portulaca oleracea (Purslane) plant - its nature and biomedical benefits, Internasional Jurnal of Boimedical Research, Nigeria.

Harvey R. A. \& Pamela C.C., 2013, Farmakologi Ulasan Bergambar, Penerbit buku kedokteran: EGC, Jakarta.

Joel G. H. \& Lee E. L., 2007, Dasar Farmakologi Terapi, Penerbit Buku Kedokteran: EGC, Jakarta

Kim Y., Sang-Won L., Sae w., Hye R. \& Eun S., 2015, Anti-inflammatory effects of Portulaca oleracea, On the LPS-induced RAW 264,7 cells, Journal of Medicinal Plant Research, 9(12): 407-411.

Lee, se-Eun, Lim Cheyeon, Kim Hyungwoo, Cho Suin, 2016, a study of the anti-inflammatory effects of the ethyl acetate fraction of the methanol extract of forsythiae fruct us, Afr. J. Tradit. Complement Altern Med. (2016) 13(5):102-113

Susanti Ari D., Ardiana dwi, Gumelar Gita P., Bening Yoshepin B., 2012, Polaritas Pelarut sebagai pertimbangan dalam pemilihan pelarut untuk ekstraksi minyak bekatul dari bekatul varietas ketan (Oriza sativa Glatinosa), Simposium Nasional RAFI FT UMS-2012, ISSN 1412-9612

Zhou Yan-Xin, Hai-Liang Xin, Su-Juan Wang, Cheng Peng \& Hong Zhang, 2015, Portulaca oleracea L.: A Review of Phytochemistry and Pharmacological Effect, Hindawi Publishing Corporation, Biomed Research Internasional 